\title{
Relevance of prognostic factors in the decision-making of stem cell transplantation in Myelodysplastic Syndromes
}

\author{
Fernando Barroso Duarte ${ }^{1 *}$, Talyta Ellen de Jesus dos Santos ${ }^{2}$, Maritza Cavalcante Barbosa ${ }^{2}$, Jacques Kaufman ${ }^{3}$, João Paulo \\ de Vasconcelos ${ }^{3}$, Romélia Pinheiro Gonçalves Lemes ${ }^{4}$, Francisco Dário Rocha ${ }^{5}$, DiegoFerreira Coutinho ${ }^{6}$, Ilana Zalcberg ${ }^{7}$, \\ Paulo Roberto Leitão de Vasconcelos ${ }^{8}$ \\ ${ }^{1}$ Hematologist Physician at the Bone Marrow Transplantation Service of Hospital Universitário Walter Cantídio. Centro de Hematologia e Hemoterapia do Ceará. Ph.D. Student of the Post-Graduate Program in Surgery, \\ ${ }^{2}$ Master's Degree in Pharmaceutical Sciences, Research Laboratory in Hemoglobinopathies and Genetics of Hematological Diseases, Universidade Federal do Ceará, Brazil \\ ${ }^{3}$ Hematologist Physician at the Bone Marrow Transplantation Service of Hospital Universitário Walter Cantídio. \\ ${ }^{4}$ Ph.D. and Full Professor of Universidade Federal do Ceará- Department of Clinical and Toxicological Analyses; Research Laboratory in Hemoglobinopathies and Genetics of Hematological Diseases, Universidade Federal do \\ Ceará, Brazil. \\ ${ }^{5}$ Pathologist Physician at Hospital Universitário Walter Cantídio. Professor at the Post-Graduate Program in Surgery -Universidade Federal do Ceará, Brazil. \\ ${ }^{6}$ Ph.D. Student at Molecular Biology Laboratory - Instituto Nacional do Câncer (INCA), Brazil. \\ ${ }^{7}$ Physician and Researcher at Instituto Nacional do Câncer (INCA) \\ ${ }^{8}$ Ph.D. in General Surgery, Department of Surgery, Universidade Federal do Ceará, Brazil.
}

\footnotetext{
Hematopoietic Cell Transplantation Service - Hospital Universitário Walter Cantídio-Universidade Federal do Ceará - Brazil

*Correspondence to: Address: Rua Capitão Francisco Pedro, 1290 - Rodolfo Teófilo Fortaleza - CE, CEP: 60430-370 Telefone: 5585999848251 E-mail: nutriquimio@uol.com.br

http://dx.doi.org/10.1590/1806-9282.62.Suppl1.25
}

\section{Abstract}

\begin{abstract}
The hematopoietic stem cell transplantation (HSCT) is the only curative alternative for Myelodysplastic Syndrome (MDS), but many patients are not eligible for this treatment, as there are several limiting factors, especially in the case of patients with low-risk MDS. The aim of this study is to discuss the factors that can guide the decision-making on referring or not a patient to HSCT. Three cases of MDS, two of which were submitted to HSCT are presented. We intend to report the difficulties in referring patients with MDS to transplant and the prognostic factors that contribute to define eligibility.
\end{abstract}

Keywords: Myelodysplastic Syndrome; Hematopoietic Stem Cell Transplantation; Prognosis

\section{INTRODUCTION}

Myelodysplastic Syndrome (MDS) is a clonal disorder characterized by cytopenia and it may be accompanied by dysmyelopoiesis cytogenetic changes, which may define prognosis $^{1,2}$. Approximately one third of the patients develop acute leukemia, in most cases, acute myelogenous leukemia, making it necessary to use prognostic scoring systems, such as IPSS, IPSS-R and WPSS. The latter has been enhanced with improved cytogenetic stratification ${ }^{3,4}$. Despite this refinement, as we better understand the molecular changes, we found that the prognostic scores, as they do not incorporate the mutations, do not fully contemplate this risk characterization ${ }^{1}$. In fact, when we are treating high-risk patients, who present with refractory anemia with excess blasts (RAEB) I and II, there is no doubt that, if the patient has the medical condition, he should be referred to hematopoietic stem cell transplantation (HSCT).
However, in low-risk patients, for whom the recommendation is a more conservative approach, we often deal with an adverse context, as due to the cytopenia many of these patients depend on transfusions of packed red blood cells and platelets, which, despite classifications, behave as high risk, with an unfavorable quality of life and life expectancy.

The study of TET2, DNMT3, TP53, JAK2, RUNX1, SF3B1, AF1 and ASXL1 mutations has shown to be significant, as it identifies the association between the tumor genomic profile and the phenotypic and clinical characteristics of the disease, thus having significant prognostic value $^{5}$. The p53 gene mutation can be found in 8 to $12 \%$ of all subtypes of MDS and is independently associated with poor prognosis, more frequently in patients with complex karyotype and 5q deletion (15 to $20 \%$ ), which may predict resistance to lenalidomide or be associated with recurrence ${ }^{6-9}$. The protein encoded by the TP53 tumor sup- 
pressor gene is a key factor in regulating the cell cycle and tumor pathogenesis. Its overexpression is related with the presence of TP53 mutations and both have been associated with poor prognosis and shorter survival ${ }^{10}$. The analysis by the immunohistochemistry of p53 protein has been considered a useful and easily applicable tool, having been observed in up to $34.4 \%$ of patients with low-risk MDS ${ }^{11}$. In addition to correlating with the presence of the mutation and indicating poor prognosis and shorter survival ${ }^{12-14}, \mathrm{p} 53$ has been identified as a parameter that can help in the indication and the outcome of $\mathrm{HSCT}^{12-15}$.

\section{Case 1}

A 70-year-old male patient was diagnosed with MDS, of refractory cytopenia with multilineage dysplasia (RCMD) subtype, according to the WHO $2008^{16}$, with intermediate-1 risk according to IPSS and very low risk, according to the R-IPSS after blood count assessment: hemoglobin, $11.4 \mathrm{~g} / \mathrm{dL}$, hematocrit, $34.4 \%$, Leukocytes$3.030 \times 10^{9} / \mathrm{L}$, platelets $9.13 \times 109 / \mathrm{L}$; myelogram: hypercellular with dysplasia $>10 \%$ in all lineages, $0.2 \%$ blasts and normal iron levels; biopsy: grade I/II diffuse fibrosis; Immunohistochemistry: CD34 + labeling in precursor cells and in some megakaryocytes,

presence oflymph nodes, CD20 labeling. Strong nuclear staining of $40 \%$ in $\mathrm{p} 53$ was observed in blast cells. The karyotype was normal $(46, \mathrm{XY})$. The patient did not respond to therapy with erythropoietin and granulocyte colony-stimulating factor (G-CSF). The disease progressed to acute leukemia with pancytopenia: Hemoglobin-9.91 g/dL, hematocrit, $29.3 \%$, leukocyte, $1.41 \times 10^{9} / \mathrm{L}$, platelets, $8.0 \times 10^{9} / \mathrm{L}$ and $10 \%$ blasts in peripheral blood. Six months after the first admission, the patient died.

\section{Case 2}

A 51-year-old male patient was diagnosed with MDS, of refractory anemia with excess blasts I (RAEB- 1$)^{16}$ sub- type, after careful analysis of blood count: hemoglobin $4.84 \mathrm{~g} / \mathrm{dL}$, hematocrit, $14.4 \%$, leukocytes, $2.03 \times 10^{9} / \mathrm{L}$, platelets, $6.52 \times 10^{9} / \mathrm{L}$ and myelogram: markedly hypocellular, presence of 5\% blasts. Bone biopsy showed hypercellularity with marked dysmegakaryopoiesis, mild dyserythropoiesis and grade I/II myelofibrosis. No metaphases were obtained at the cytogenetic analysis. Immunohistochemistry was positive for CD34 in several precursor cells and megakaryocytes. Lymphoid nodules were observed, labeling CD20. The p53 expression was positive in $4 \%$ of analyzed cells and the hypomethylating azacitidine was requested, but it was not available. The patient was referred to related allogeneic HSCT. The conditioning regimen consisted of fludarabine $120 \mathrm{mg} / \mathrm{m}^{2}$ and melphalan $180 \mathrm{mg} / \mathrm{m}^{2}$. After the HSCT, the patient developed a severe infectious condition and died.

\section{Case 3}

A 56-year-old male patient was diagnosed with hypocellular MDS after ruling out aplasia. The blood count showed pancytopenia: hemoglobin, $8.0 \mathrm{~g} / \mathrm{dL}$, hematocrit, $24.2 \%$ and leukocytes, $3.0 \times 10^{9} / \mathrm{L}$. The myelogram and bone marrow biopsy showed hypocellular marrow with reticulin stain, indicating the presence of grade II marrow fibrosis (MF-2). Cytogenetics did not provide enough metaphases for analysis. The immunohistochemistry was positive for $\mathrm{CD} 34$, with megakaryocyte labeling and there were lymphoid nodules, labeling CD20. The p53 protein labeling was negative. The patient was referred to HSCT with related donor. The conditioning regimen consisted of fludarabine $120 \mathrm{mg} / \mathrm{m}^{2}$ and melphalan $180 \mathrm{mg} / \mathrm{m}^{2}$. Six months after transplantation, the patient is stable and in complete remission.

\section{Discussion}

Although an increased understanding of MDS has led to the emergence of new approaches to clinical manage-
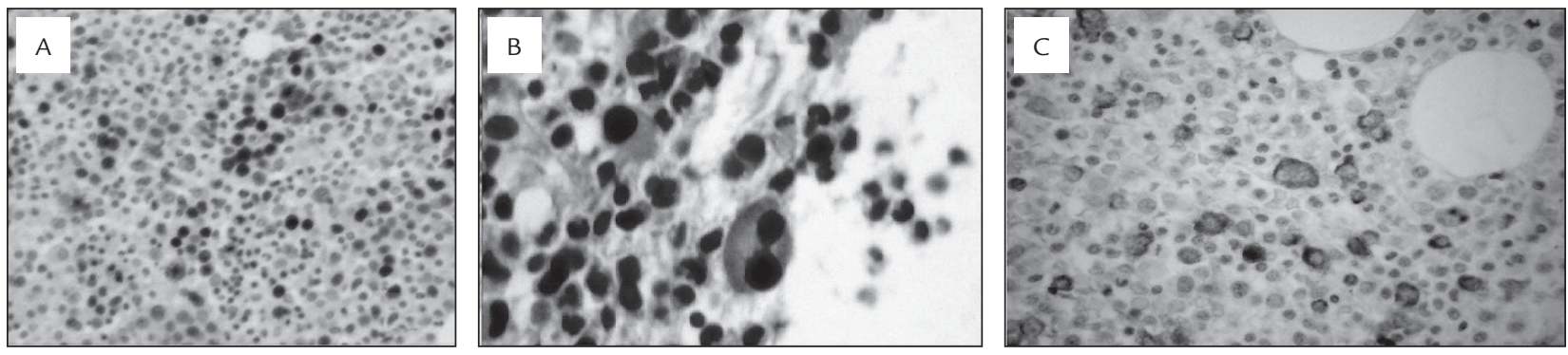

FIGURE 1. Images from Case 1. A- Strong nuclear staining (40\%) of p53 protein in granulocytic precursors. B- Myelogram showing cellularity of approximately $70 \%$. Dysplastic megakaryocytes, erythroblasts in the peritrabecular position (ALIP). Hematoxylin. Magnification: 1000x. C- Positive CD34+ labeling in precursor cells and in some megakaryocytes. StreptavidinBiotin. Magnification: 400x. 
ment and new therapeutic modalities, allogeneic hematopoietic cells is still the only curative therapy ${ }^{1,17}$. In MDS, factors considered critical in HSCT indication such as age, comorbidities, ideal transplantation time and conditioning regimen have limited its practice to less than $5 \%$ of patients, after careful selection ${ }^{18-21}$. Regarding therapeutic regimens, protocols with low doses of radiation or alkylating agents have been used in an attempt to minimize treatment effects related to toxicity and graft-versus-host disease ${ }^{22.23}$. It is expected that, with the development of new preventive and therapeutic strategies for better post-transplantation management, most patients with MDS can benefit from better survival. Generally, HSCT is indicated for patients with unfavorable prognostic features, according to the World Health Organization and classification systems such as IPSS and IPSS-R. Some characteristics have been reported as being indicative of HSCT, such as complex karyotype, bone marrow fibrosis markers and immature cells in the bone marrow. Clinical conditions such as intense need for transfusion, iron overload or recurrent clinical infections are also important factors in determining the possibility of $\mathrm{HSCT}^{24-26}$. Although increased frequency of high-risk disease phenotypes, such as unfavorable cytogenetics and possibly higher rates of mortality due to transplantation limit its use in older patients, ${ }^{27}$ McClune et al., analyzed the results of 1.080 patients with AML or MDS undergoing HSCT and concluded that age alone should not be considered as a contraindication to HSCT. Patients undergoing HSCT can benefit from approximately 30 to $50 \%$ diseasefree survival, depending on patient and disease characteristics, conditioning regimen, hematopoietic cell donors and transplantation procedure strategies ${ }^{28,29}$. In patients with low-risk MDS, HSCT constitutes a challenge, as the best time to perform it has not been well-established yet and it is a relevant issue to be discussed, considering the most significant factors that may indicate the viability and success of the procedure ${ }^{21}$.

This article reports two cases of low-risk patients and one high-risk case, which according to the literature, showed clinical and hematological indications favorable to HSCT. The striking characteristic in all cases was the presence of fibrosis and lymphoid nodules in the bone marrow. Two patients were positive for the p53 protein expression and died. The first died before undergoing HSCT and the second died twenty days after the procedure, due to a severe infection. The third case is a patient who was negative for p53 expression, had not previously use antithymocyte globulin $^{3}$, but was submitted to HSCT, progressed well and, nine months later, had no complications.
There are few studies that investigate the role of p53 expression in patients with low-risk MDS. In a previous study, we observed that patients with p53 expression had a higher frequency of bone marrow fibrosis and lower survival ${ }^{12}$.

Studies have suggested the participation of MDS patients in research protocols, particularly those with complex karyotypes and mutations that can indicate HSCT, for risk assessment and potential benefits of each available therapeutic approach ${ }^{10,30}$. Considering the outcome of each reported patient, added to the literature data, we suggest that the expression of $\mathrm{p} 53$ protein, in addition to being an important prognostic marker, can help in HSCT indication associated with the presence of fibrosis. However, further studies are needed to confirm this hypothesis.

\section{Resumo}

Relevância dos fatores prognósticos na decisão do transplante de células-tronco na Síndrome Mielodisplásica

O transplante de células-tronco hematopoéticas (TCTH) é a única alternativa curativa para Síndrome Mielodisplásica (SMD), porém muitos pacientes não são elegíveis para esta opção, pois existem diversos fatores limitantes, principalmente no caso de pacientes com SMD de baixo risco. O objetivo do estudo é discutir os fatores que podem orientar a decisão no encaminhamento ou não para o TCTH. São apresentados três casos de SMD, dos quais dois foram submetidos ao TCTH. Nos propomos a relatar as dificuldades no encaminhamento dos pacientes com SMD ao transplante e os fatores prognósticos que contribuem para definir a elegibilidade.

Palavras-Chave: Síndrome Mielodisplásica; Transplante de Células-Tronco Hematopoéticas; Prognóstico.

\section{References}

1. Otrock ZK, Tiu RV, Maciejewski JP, Sekeres MA. The need for additional genetic markers for MDS stratification: what does the future hold for prognostication? Expert Rev Hematol. 2013;6:59-68.

2. Bejar R, Stevenson K, Abdel-Wahab O, Galili N, Nilsson B, Garcia-Manero $\mathrm{G}$, et al. BLClinical effect of point mutations in myelodysplastic syndromes.N Engl J Med. 2011;364:2496-506.

3. Malcovati L,Hellström-Lindberg E,Bowen D, Adès L,Cermak J, Del Cañizo C, et al. Diagnosis and treatment of primary myelodysplastic syndromes in adults: recommendations from the European Leukemia Net. Blood. 2013; 24:2943-64.

4. Walter MJ, Shen D, Ding L. Clonal architecture of secondary acute myeloid leukemia. N Engl J Med. 2012;366:1090-8.

5. Papaemmanuil E, Gerstung M, Malcovati L, Tauro S, Gundem G, Van Loo P, et al. Clinical and biological implications of driver mutations in myelodysplastic syndromes. Blood. 2013;122:3616-27.

6. National Comprehensive Cancer Network. Version 1.2016. Avaiable from: http://www.cibmtr.org.

7. Kulasekararaj AG, Smith AE, Mian SA, Mohamedali AM, Krishnamurthy P, Lea NC. TP53 mutations in myelodysplastic syndrome are strongly correlated with aberrations of chromosome 5, and correlate with adverse prognosis. Br J Haematol. 2013;160:660-72. 
8. Jädersten M, Saft L, Smith A, Kulasekararaj A, Pomplun S, Göhring G, et al. TP53 Mutations in Low-Risk Myelodysplastic Syndromes With del(5q) Predict Disease Progression. J Clin Oncol. 2011;29:1971-9.

9. Kita-Sasai Y, Horiike S, Misawa S, Kaneko H, Kobayashi M, Nakao M, et al. International prognostic scoring system and TP53 mutations are independent prognostic indicators for patients with myelodysplastic syndrome. $\mathrm{Br} \mathrm{J}$ Haematol. 2001;115:309-12.

10. Bejar R, Stevenson KE, Caughey B, Lindsley RC, Mar BG, Stojanov P, et al. Somatic mutations predict poor outcome in patients with myelodysplastic syndrome after hematopoietic stem-cell transplantation. J Clin Oncol. 2014;32:2691-8

11. Duarte FB, Goncalves RP, Barbosa MC, Rocha Filho FD, de Jesus dos Santos TE, Nogueira dos Santos T, et al. Tumor suppressor p53 protein expression: prognostic significance in patients with low-risk myelodysplastic syndrome. Rev Bras Hematol Hemother. 2014;36:196-201.

12. Chang H, Jiang AM, Qi CX. Aberrant nuclear p53 expression predicts hemizygous $17 \mathrm{p}$ (TP53) deletion in chronic lymphocytic leukemia. Am J Clin Pathol. 20101;30:70-4

13. Kamata H, Mitani S, Fujiwara M, Aoki N, Okada S, Mori S. Mutation of the p53 tumour suppressor gene and overexpression of its protein in 62 Japanese non-Hodgkin's lymphomas. Clin Exp Med. 2007;7:39-46.

14. Saft L, Karimi M, Ghaderi M, Matolcsy A, Mufti GJ, Kulasekararaj A, et al. P53 protein expression independetly predicts outcome in patients with lower- risk myelodysplastic syndromes with Del (5q). Haematology. 2014;99:1041-9.

15. Honkaniemi E, Mattsson K, Barbany G, Sander B, Gustafsson B. Elevated p53 protein expression; a predictor of relapse in rare chronic myeloid malignancies in children? Pediatr Hematol Oncol. 2014;31:327-39.

16. Swerdlow SH, Campo E, Harris NL, Jaffe ES, Pileri SA, Stein H, et al. WHO Classification of Tumours of haematopoietic and lymphoid tissues. $4^{\text {th }}$ ed. Geneva: WHO Press; 2008. p.1-439

17. Ades L, Itzykson R, Fenaux P. Myelodysplastic syndromes. Lancet. 2014;383:2239-52.

18. Sekeres MA, Schoonen WM, Kantarjian H, List A, Frizek J, Paquette R, et al. Characteristics of US patients with myelodysplastic syndromes: results of six cross-sectional physician surveys. J Natl Cancer Inst. 2008; $100: 1542-51$
19. Alessandrino EP, Amadori S, Barosi G, Cazzola M, Grossi A, Liberato LN, et al. Evidence-and consensus-based practice guidelines for the therapy of primary myelodysplastic syndromes. A statement from the Italian Society of Hematology. Haematologica. 2002;87:1286-306.

20. Bowen D, Culligan D, Jowitt S, Kelsey S, Mufti G, Oscier D, et al. Guidelines for the diagnosis and therapy of adult myelodysplastic syndromes. Br J Haematol.2003;120:187-200.

21. McClune BL, Weisdorf DJ, Pedersen TL, Tunes da Silva G, Tallman MS, Sierra J, et al. Effect of Age on Outcome of Reduced-Intensity Hematopoietic Cell Transplantation for Older Patients With Acute Myeloid Leukemia in First Complete Remission or With Myelodysplastic Syndrome. J Clin Oncol. 2010;28:1878-87.

22. Choi EJ, Lee JH, Lee JH, Kim DY, Park HS, Seol M, et al. Non-myeloablative conditioning for lower-risk myelodysplastic syndrome with bone marrow blasts less than 5\%-a feasibility study. Ann Hematol. 2016;95:1151-61.

23. McSweeney PA, Niederwieser D, Shizuru JA, Sandmaier BM, Molina AJ, Maloney DG, et al. Hematopoietic cell transplantation in older patients with hematologic malignancies: Replacing high-dose cytotoxic therapy with graftversus-tumor effects. Blood. 2001;97:3390-400.

24. Haferlach T, Nagata Y, Grossmann V, Okuno Y, Bacher U, Nagae G, et al. Landscape of genetic lesions in 944 patients with myelodysplastic syndromes. Leukemia. 2014;28:241-7.

25. Kroger N, Zabelina T, van Biezen A, Brand R, Niederwieser D, Martino R, et al. Allogeneic stem cell transplantation for myelodysplastic syndromes with bone marrow fibrosis. Haematologica. 2011;96:291-7.

26. Malcovati L, Porta MG, Pascutto C, Invernizzi R, Boni M,Travaglino E, et al. Prognostic factors and life expectancy in myelodysplastic syndromes classified according to WHO criteria: a basis for clinical decision making. J Clin Oncol. 2005;23:7594-603.

27. Appelbaum FR, Gundacker H, Head DR, Slovak ML, Willman CL, Godwin JE, et al. Age and acute myeloid leukemia. Blood 2006;107:3481-5.

28. Zeidan AM, Linhares Y, Gore SD. Current therapy of myelodysplastic syndromes. Blood Rev. 2013;27:243-59.

29. Pasquini MC, Wang Z. Current use of hematopoietic stem cell transplantation: CIBMTR Summary Slides, 2013. Avaiable from: www.cibmtr.org/ referencecenter/slidesreports/summaryslides/Pages/index.aspx.

30. de Witte T. Recommendations of allogeneic transplantation for patients with MDS. Avaiable from: http://www.mds-foundation.org/wp content uploads/2015/12/AllogeneicHematopoieticTransplantation.pdf. 